\title{
Leaf nutrient content on seven plum cultivars with grafted by budding or own-rooted trees
}

\author{
Newton Alex Mayer ${ }^{1}$, Bernardo Ueno ${ }^{1}$, Gilberto Nava ${ }^{1}$, Tainá Rodrigues das Neves ${ }^{2}$ \\ Abstract - Several studies have been conducted in Brazil with rooting of plum scion cultivars, \\ however, it is not known the performance and benefits of own-rooted trees at field. This study \\ aimed to evaluate the leaf nutrient content ( $, \mathrm{P}, \mathrm{K}, \mathrm{Ca}, \mathrm{Mg}, \mathrm{Fe}, \mathrm{Mn}, \mathrm{Zn}, \mathrm{Cu}$ and $\mathrm{B}$ ) in seven \\ Japanese plum cultivars (Prunus salicina) on the $2^{\text {nd }}$ and $3^{\text {rd }}$ year after field planting, whose nursery \\ trees were produced by "T-inverted" budding method over 'Capdeboscq' peach (P. persica) or \\ by own-rooted hardwood cuttings. The experimental design was in randomized blocks, factorial \\ 7 x 2 (cultivars x nursery tree types), with five replicates of one tree per plot. We conclude that \\ leaf nutrient content of Japanese plums varies among cultivars; however there is no cultivar that \\ stands out in all macro and micronutrients evaluated. $\mathrm{K}, \mathrm{Ca}$ and $\mathrm{Mn}$ leaf contents, when affected \\ by nursery tree types tested, were always higher in own-rooted trees. However, $\mathrm{Mg}$ leaf contents, \\ when affected by nursery tree types tested, were always higher in budded trees on 'Capdeboscq' \\ peach. Own-rooted plum trees of 'Amarelinha', 'Blood Plum', 'Pluma-7' and 'Reubennel' presented \\ higher Mn leaf contents, in relation to budded trees of these cultivars on 'Capdeboscq'. Own-rooted \\ 'Cerejinha' plum trees have highest $\mathrm{K}$ leaf content and also increase the agronomic interpretation \\ class in relation to the budded trees of this cultivar on 'Capdeboscq'. \\ Index terms: Rosaceae, Prunus salicina Lindl., nutrition, propagation method.

\section{Teores de nutrientes foliares em sete cultivares de ameixeiras com plantas enxertadas por borbulhia ou autoenraizadas}

\section{Corresponding author:} alex.mayer@embrapa.br

Received: April 27, 2017. Accepted: December 11, 2017.

Copyright: All the contents of this journal, except where otherwise noted, is licensed under a Creative Commons Attribution License.

\section{(cc) $\mathrm{EY}$}

Resumo - Diversos estudos foram realizados no Brasil sobre enraizamento de cultivares-copa de ameixeira; entretanto, não são conhecidos o desempenho e os benefícios de mudas autoenraizadas a campo. O presente trabalho teve por objetivo avaliar os teores de nutrientes foliares $(\mathrm{N}, \mathrm{P}, \mathrm{K}$, $\mathrm{Ca}, \mathrm{Mg}, \mathrm{Fe}, \mathrm{Mn}, \mathrm{Zn}, \mathrm{Cu}$ e B) em sete cultivares de ameixeiras-japonesas (Prunus salicina) no $2^{\circ}$ e $3^{\circ}$ anos após o plantio no campo, cujas mudas foram produzidas por enxertia em "T-invertido" sobre o pessegueiro 'Capdeboscq' ( $P$. persica) ou por autoenraizamento de estacas lenhosas. O delineamento experimental foi em blocos ao acaso, fatorial $7 \times 2$ (cultivares $\times$ tipos de muda), com cinco repetições de uma planta por parcela. Com os resultados obtidos, foi possível concluir que os teores de nutrientes foliares de ameixeiras-japonesas variam entre as cultivares, porém não há uma cultivar que se destaque em todos os macro e micronutrientes avaliados. Os teores foliares de $\mathrm{K}$, Ca e de $\mathrm{Mn}$, quando influenciados pelos tipos de mudas testadas, foram sempre maiores nas plantas autoenraizadas. Contudo, os teores foliares de $\mathrm{Mg}$, quando influenciados pelos tipos de mudas testadas, foram sempre maiores nas plantas enxertadas em 'Capdeboscq'. Plantas autoenraizadas das cultivares Amarelinha, Blood Plum, Pluma-7 e Reubennel apresentam maiores teores foliares de $\mathrm{Mn}$, em relação às plantas enxertadas dessas cultivares sobre 'Capdeboscq'. Plantas autoenraizadas da cv. Cerejinha apresentam maiores teores foliares de $\mathrm{K}$, em relação às plantas enxertadas desta cultivar sobre 'Capdeboscq' e, inclusive, elevam a classe de interpretação agronômica.

Termos de Indexação: Rosaceae, Prunus salicina Lindl., nutrição, método de propagação.

\footnotetext{
${ }^{1}$ Agricultural Engineer Dr., Embrapa Clima Temperado, BR 392, km 78, Caixa Postal 403, CEP 96010-971, Pelotas, Rio Grande do Sul State, Brazil. E-mail: alex.mayer@embrapa.br; bernardo.ueno@embrapa.br; gilberto.nava@embrapa.br

${ }^{2}$ Environmental management student and scolarship at Embrapa Clima Temperado, BR 392, km 78, Caixa Postal 403, CEP 96010-971, Pelotas, Rio Grande do Sul State, Brazil. E-mail: taina4919@hotmail.com
} 


\section{Introduction}

The production of plum nursery trees in Brazil has traditionally been carried out by the grafting of active bud ("T-inverted" or "T-normal" budding methods) of the scion cultivar on peach seedlings, forming an interspecific combination. In this conventional system, the nursery is made under field conditions, the nursery trees are commercialized in bare root and it takes, on average, 18 months for its production. The short period of commercialization of the nursery trees, restricted to the dormancy stage and the necessity of planting in a few days after the pull off are other disadvantages of the system (PEREIRA; MAYER, 2005). Hammerschlag and Scorza (1991) point out that the adoption of rootstocks and the choice of propagation methods are only justified when the rootstocks are really necessary, if they present resistance characteristics to particular problems of soil or pathogens, besides the viable production costs and the easiness of propagation. The use of varietal pits mixtures of several peach-tree cultivars to form rootstocks, a practice that still common in many nurseries that produce this species in Rio Grande do Sul, does not allow to know and to perpetuate the cultivar used, as well as does not exist vigor homogeneity and reactions to the existing biotic and abiotic factors in the climate and soil (PEREIRA; MAYER, 2005; MAYER et al., 2014a). The seeds of the 'Capdeboscq' scion of free pollination, another material also used to produce rootstock, confer susceptibility to the Meloidogyne spp. and the Mesocriconema xenoplax nematodes (MAUCH et al., 1991; CARNEIRO et al., 1998).

Alternatively, the nursery trees can be produced by some vegetative method that enables the rooting of the cultivar itself. Named own-rooted, these kind of trees do not require grafting or budding and, thus, there is no rootstock and the risks of incompatibility are excluded, being considered a situation closer to natural. The ownrooted scion is commercially used in Brazil for several crops, and in fruit trees the method is used in fig tree, guava tree, blueberry tree, blackberry and olive tree. In peach tree, the own-rooted by woodcuts was proposed for the formation of dense orchards in order to reduce planting costs (COUVILLON, 1985). The mature peach trees, on their own roots, presented higher productive efficiency, were more tolerant to drought and produced larger fruits under conditions of water stress, compared to the plants grafted on seedlings (COUVILLON, 1985; COUVILLON et al., 1989). The micropropagated scion cultivars, in addition to allowing the production of virus-free plants in a short period of time, presented higher yield and productive efficiency than those grafted (HAMMERSCHLAG; SCORZA, 1991). However, the own-rooted 'Redhaven' peach trees showed lower longevity and higher mortality due to Peach Tree Short Life (PTSL), in areas with a history of the syndrome in the Southeast of the United States (REIGHARD et al., 1990).

The leaves of own-rooted peach trees presented higher calcium $(\mathrm{Ca})$ and magnesium $(\mathrm{Mg})$ contents compared to the same cultivars grafted on rootstocks multiplied by seeds (COUVILLON, 1982). In the case of grafted plants, the grafting point may represent a barrier to the translocation of these elements to the scion (COUVILLON, 1982). Adequate Ca contents are fundamental for cell wall integrity and cell membrane selectivity and they prevent the occurrence of physiological disturbances in fruits (MANGANARIS et al., 2005). However, own-rooted 'Stanley' plum propagated by micropropagation and evaluated in the field did not present significant differences in the leaf nutrient content of nitrogen $(\mathrm{N})$, phosphorus $(\mathrm{P})$, potassium $(\mathrm{K}), \mathrm{Ca}, \mathrm{Mg}$ and iron $(\mathrm{Fe})$ and on the physical characteristics of fruits and pits, compared to the plants grafted on 'Dzhanka 4' multiplied by seed or ' $\mathrm{GF}$ 655/2' micropropagated (POPOV; ZHIVONDOV, 2002).

Several studies were carried out in Brazil using cuttings, air-layering, or tissue culture to produce ownrooted nursery trees of several plum scion cultivars (DUTRA et al., 1997; TONIETTO et al., 2001; SCHWENGBER et al., 2002; TOFANELLI et al., 2002; CASTRO; MEDEIROS, 2007; BANDEIRA et al., 2013). However, it is not known the behavior in the field of own-rooted plums and their real benefits in relation to the traditional nursery trees grafted on peach trees of naked root. In general, the plums are more tolerant to soil flooding than peach trees (GUERRA et al., 1992; REIGHARD; LORETI, 2008; MESCHIMIDT et al., 2015) and, as hypothesis, the absence of a grafting point in own-rooted plum trees can be beneficial to plant nutrition.

The aim of this study was to evaluate the leaf nutrient contents in seven plum cultivars (Prunus salicina) in the $2^{\text {nd }}$ and $3^{\text {rd }}$ year after the field planting, whose nursery trees were produced by own-rooted of hardwood cuttings or by grafting ("T-inverted" budding method) on the 'Capdeboscq' peach.

\section{Material And Methods}

The plum nursery trees (Prunus salicina Lindl) of the cultivars Amarelinha, Blood Plum, Cerejinha, Quinze de Novembro, Pluma-7, Reubennel and Santa Rita were produced in the Nursery Frutplan Mudas Ltda. (PelotasRS) by two different systems: a) own-rooted nursery trees, propagated by hardwood cuttings and kept in a plastic bag $(35 \times 19 \mathrm{~cm})$ containing commercial substrate; b) nursery trees grafted by "T-inverted" budding method on 'Capdeboscq' peach [Prunus persica (L.) Batsch] multiplied by seeds, produced under field conditions (bare root). The nursery trees, standardized with $50 \mathrm{~cm}$ of height, 
were planted in the field on October $10^{\text {th }}, 2012$, with the spacing of $6 \times 3 \mathrm{~m}$, in a rural property ( $212 \mathrm{~m}$ of altitude) located in the $8^{\text {th }}$ district of Pelotas-RS, Brazil. The soil of the experimental area was classified as "Argissolo Bruno acinzentado" (EMBRAPA, 2013), predominantly sandy and with average content of $16 \%$ of clay. The results of the physico-chemical analysis are shown in Table $\mathbf{1 .}$

The plants were trained in an open-vase format without tutoring, with four to six scaffolds per tree (RASEIRA et al., 2003), and the fertilizations carried out based on the interpretation of leaf analyzes, shoot growth and yield expectation (CQFS-RS/SC, 2004). In the first three years after planting, only $\mathrm{N}$ was applied at doses of 30,60 and $90 \mathrm{~kg} \mathrm{ha}^{-1}$ for 2012, 2013 and 2014, respectively. In 2015, besides $\mathrm{N}$ ( $\left.90 \mathrm{~kg} \mathrm{ha}^{-1}\right), 30$ $\mathrm{kg} \mathrm{ha}^{-1}$ of $\mathrm{K}_{2} \mathrm{O}$ was also applied. The $\mathrm{N}$ applications were fractionated three times, being $50 \%$ at the beginning of the growth, $30 \%$ after fruit thinning and $20 \%$ after the harvest. The $\mathrm{K}$ was applied in a single dose at the beginning of growth, together with the first application of N. Since the leaf contents of $\mathrm{P}$ were always higher than $0.09 \%$, it was not necessary to apply this nutrient.

The leaf samplings were made in December 2014 and 2015 , approximately between the $13^{\text {th }}$ and $15^{\text {th }}$ weeks after full bloom. A total of 100 complete leaves (limbus with petiole) were collected at random from each plot, in the year average portion of shoots located in the middle third of the tree, according to the recommendations of Freire and Magnani (2005). The samples were disposed in identified paper bags and immediately sent to the
Embrapa Clima Temperado Plant Nutrition Laboratory for chemical analysis. The leaf contents of macronutrients were determined: N, P, K, Calcium $(\mathrm{Ca})$ and Magnesium $(\mathrm{Mg})$, expressed in \%; and of micronutrients: $\mathrm{Fe}$, manganese $(\mathrm{Mn})$, zinc $(\mathrm{Zn})$, copper $(\mathrm{Cu})$ and boron $(\mathrm{B})$, expressed in $\mathrm{mg} \mathrm{kg}^{-1}$, according to the methodologies established by Tedesco et al. (1995) and CQFS-RS / SC (2016). In 2014 and 2015, four sub-samples of soil per block were also collected in the 0 to $0.20 \mathrm{~m}$ deep layer, which together formed a composed sample per block. The $\mathrm{pH}$, organic matter (\%), $\mathrm{P}$ and $\mathrm{K}\left(\mathrm{mg}^{-\mathrm{dm}^{-3}}\right)$, $\mathrm{Ca}, \mathrm{Mg}, \mathrm{Al}, \mathrm{H}+\mathrm{Al}, \mathrm{K}\left(\mathrm{cmol}_{\mathrm{c}} \mathrm{dm}^{-3}\right)$, base and aluminum saturation and cation exchange capacity $\left(\mathrm{CEC}_{\mathrm{pH}} 7\right)$ were evaluated (Table 1), to assist in the interpretation of leaf analysis data, as recommended by Freire and Magnani (2005). Monthly rainfall data were recorded in the second semester of each year, at the Embrapa Clima Temperado Headquarters (Table 2), at a distance of $29 \mathrm{~km}$, straight from the experiment site.

The experimental design was in randomized complete block design with a factorial of $7 \times 2$, with five replications. The seven levels of the cultivar factor were 'Amarelinha', 'Blood Plum', 'Cerejinha', 'Quinze de Novembro', 'Pluma-7', 'Reubennel' and 'Santa Rita', and the two levels of the nursery tree type factor were own-rooted and grafted by budding. Each plot consisted of one plant, totaling 70 plants (= 70 plots). The data of each year of sampling were analyzed separately, being submitted to the analysis of variance, by the F test, and the averages compared by the Tukey test, at the level of $5 \%$ of probability, using the Estat software (ESTAT, 1994).

Table 1. Results and interpretation of the soil analysis of the samples $(0-20 \mathrm{~cm})$ from the five experimental blocks, in 2014 and 2015. Embrapa Clima Temperado, Pelotas-RS, 2016.

\begin{tabular}{|c|c|c|c|c|c|c|c|c|c|c|c|c|}
\hline \multirow{2}{*}{ Block } & \multirow{2}{*}{$\begin{array}{c}\mathrm{pH}_{\text {water }} \\
1: 1\end{array}$} & \multirow{2}{*}{$\begin{array}{l}\text { O.M. } \\
(\%)\end{array}$} & \multirow{2}{*}{$\begin{array}{l}\text { Clay } \\
(\%)\end{array}$} & \multirow{2}{*}{\multicolumn{2}{|c|}{$\begin{array}{c}\mathrm{P} \\
----\mathrm{mg} \mathrm{dm}^{-3}----\end{array}$}} & \multirow{2}{*}{\multicolumn{3}{|c|}{$\begin{array}{ccc}\mathrm{Ca} & \mathrm{Mg} \quad \mathrm{Al} \\
& -\end{array}$}} & $\mathrm{H}+\mathrm{Al}$ & \multicolumn{2}{|c|}{ Saturation $(\%)$} & \multirow{2}{*}{$\begin{array}{l}\mathrm{CEC} \\
\mathrm{pH} 7\end{array}$} \\
\hline & & & & & & & & & & $\mathrm{Al}$ & Bases & \\
\hline \multicolumn{13}{|c|}{2014} \\
\hline 01 & $6.6(\mathrm{H})$ & $2.1(\mathrm{~L})$ & 18 & $9.9(\mathrm{VL})$ & $99(\mathrm{H})$ & $4.3(\mathrm{H})$ & $1.0(\mathrm{M})$ & 0.0 & 2.0 & 0,0 & 74 & 7.6 \\
\hline 02 & $6.6(\mathrm{H})$ & $2.0(\mathrm{~L})$ & 17 & $11.6(\mathrm{~L})$ & $99(\mathrm{H})$ & $4.1(\mathrm{H})$ & $0.8(\mathrm{M})$ & 0.0 & 2.0 & 0.0 & 72 & 7.2 \\
\hline 03 & $6.8(\mathrm{H})$ & $1.8(\mathrm{~L})$ & 17 & $9.4(\mathrm{VL})$ & $105(\mathrm{H})$ & $4.3(\mathrm{H})$ & $0.9(\mathrm{M})$ & 0.0 & 1.6 & 0.0 & 77 & 7.1 \\
\hline 04 & $6.7(\mathrm{H})$ & $2.1(\mathrm{~L})$ & 17 & $4.2(\mathrm{VL})$ & $101(\mathrm{H})$ & $4.5(\mathrm{H})$ & $1.1(\mathrm{H})$ & 0.0 & 2.1 & 0.0 & 74 & 8.0 \\
\hline 05 & $6.9(\mathrm{H})$ & $2.2(\mathrm{~L})$ & 16 & $6.6(\mathrm{VL})$ & $117(\mathrm{H})$ & $4.6(\mathrm{H})$ & $1.0(\mathrm{M})$ & 0.0 & 1.5 & 0.0 & 80 & 7.4 \\
\hline \multicolumn{13}{|c|}{2015} \\
\hline 01 & $6.3(\mathrm{H})$ & $1.9(\mathrm{~L})$ & 15 & $8.7(\mathrm{VL})$ & $128(\mathrm{VH})$ & $3.8(\mathrm{M})$ & $1.4(\mathrm{H})$ & 0.0 & 1.8 & 0.0 & 75 & 7.3 \\
\hline 02 & $6.7(\mathrm{H})$ & $1.5(\mathrm{~L})$ & 14 & $8.0(\mathrm{VL})$ & $116(\mathrm{H})$ & $3.4(\mathrm{M})$ & $2.6(\mathrm{H})$ & 0.0 & 1.8 & 0.0 & 78 & 8.1 \\
\hline 03 & $6.5(\mathrm{H})$ & $2.0(\mathrm{~L})$ & 15 & $6.4(\mathrm{VL})$ & $139(\mathrm{H})$ & $4.0(\mathrm{M})$ & $1.5(\mathrm{H})$ & 0.0 & 2.1 & 0.0 & 74 & 8.0 \\
\hline 04 & $6.6(\mathrm{H})$ & $1.4(\mathrm{~L})$ & 14 & $3.3(\mathrm{VL})$ & $96(\mathrm{H})$ & $4.1(\mathrm{H})$ & $1.4(\mathrm{H})$ & 0.0 & 1.8 & 0.0 & 76 & 7.5 \\
\hline 05 & $6.7(\mathrm{H})$ & $1.7(\mathrm{~L})$ & 14 & $5.7(\mathrm{VL})$ & $98(\mathrm{H})$ & $4.3(\mathrm{H})$ & $1.6(\mathrm{H})$ & 0.0 & 1.8 & 0.0 & 78 & 8.0 \\
\hline
\end{tabular}

*Interpretation of chemical analyzes (CQFS-RS/SC, 2016): $\mathrm{VL}=$ very low; $\mathrm{L}=$ low; $\mathrm{M}=$ medium; $\mathrm{H}=$ high; $\mathrm{VH}=$ very high. 
Table 2. Monthly total rainfall registered at Embrapa Clima Temperado Headquarters (3140'59.1' S; 52²6'10.39' W; $57 \mathrm{~m}$ altitude), in the second semester of each year of evaluations. Embrapa Clima Temperado, Pelotas-RS, 2016.

\begin{tabular}{cccc}
\hline Month & Total Rainfall (mm) in 2014 & Total Rainfall (mm) in 2015 & $\begin{array}{c}\text { Total Rainfall (mm) } \\
\text { historic average (1984-2010) }\end{array}$ \\
\hline July & 204.4 & 205.7 & 120.0 \\
August & 82.0 & 116.3 & 122.9 \\
September & 179.8 & 277.8 & 136.7 \\
October & 213.8 & 321.4 & 117.7 \\
November & 91.9 & 192.2 & 111.0 \\
December & 148.7 & 261.8 & 108.6 \\
\hline
\end{tabular}

\section{Results and Discussion}

Figure 1 shows the effects of the two tested factors on leaf macronutrient contents. Regardless of the year of evaluation, there was no interaction between cultivar and nursery tree type for $\mathrm{N}$ and $\mathrm{P}$ leaf contents, as there was no main effect for the nursery tree type factor for these nutrients (Figure 1). In relation to the cultivar factor, 'Santa Rita', 'Pluma-7' and 'Cerejinha', in both years, showed the highest $\mathrm{N}$ levels, with $\mathrm{N}$ average of these cultivars $(2.77 \%)$, approximately $17 \%$ higher than the others $(2.37 \%)$. The highest $\mathrm{N}$ leaf content corresponds to the highest initial growth of the Santa Rita cultivar (MAYER et al., 2014), since, generally, $\mathrm{N}$ is the nutrient that is most related to the increase of vigor in fruit plants (NAVA et al., 2010). In 2014 and 2015, for most cultivars, the $\mathrm{N}$ content is in the sufficiency range considered normal (2.31 - 2.80\%) (CQFS-RS/SC, 2016), indicating the adequate management of nitrogen fertilization during the plant growth phase.

Although the soil P levels were considered to be very low (Table 1), the leaf nutrient contents (Figure 1) were in the normal or above normal range (CQFS-RS/ SC, 2016), as observed for all cultivars in 2015. This corroborates with the results already found for other temperate fruits such as apple and pear tree, which are rarely deficient in P (BRUNETTO et al., 2015; NAVA et al., 2017), which is mainly due to the longer period they are able to absorb the nutrient from the soil, as well as the association of the roots of these trees with mycorrhizal fungi hyphae, as verified by Nava et al. (2016) for the feijoa tree. In 2014, the Santa Rita cultivar showed to be superior to the Amarelinha cultivar, but it did not present different $\mathrm{P}$ leaf contents in relation to the other evaluated cultivars.

For the $\mathrm{K}$ leaf contents, there was interaction between the factors studied in the two years of evaluation. The $\mathrm{K}$ contents were within the normal range, above normal or excessive (CQFS-RS/SC, 2016), depending on the year and/or the cultivar combination and the nursery tree type (Figure 1 and 2). In addition to the fact that the evaluated cultivars possibly are efficient in absorbing the nutrient, the $\mathrm{K}$ leaf contents never below normal can also be related to the high $\mathrm{K}$ content in the soil (Table 1), a fact that has already been proven in others nutritional surveys carried out in Rio Grande do Sul (FREIRE, 2002) with the plum culture. The own-rooted nursery tree of the Cerejinha and Reubennel cultivars raised the $\mathrm{K}$ interpretation class for excessive in 2015 (Figure 2), but with K contents statistically similar to the Santa Rita and Pluma-7 cultivars. Still in 2015, the grafted plants of the Blood Plum cultivar presented higher K contents than the Quinze de Novembro cultivar, but it did not differ significantly from the others. In 2014, the own-rooted plants of the Reubennel, Cerejinha and Blood Plum cultivars presented the highest $\mathrm{K}$ contents, in relation to the cv. Quinze de Novembro. For the grafted plants, the Reubemel cultivar was the one that stood out this year. In the interaction for the nursery tree types within cultivars, in 2014, the Cerejinha and Pluma-7 cultivars, when own-rooted, had higher $\mathrm{K}$ contents (average of $2.22 \%$ ) than when they were grafted (average of $1.87 \%$ ), with a difference of approximately $19 \%$ in favor of the own-rooted ones. In 2015, the own-rooted trees presented higher $\mathrm{K}$ contents $(2.98 \%)$ than the grafted ones $(2.53 \%)$, but for the Cerejinha and Reubennel cultivars (Figure 2). Differences in morphology and root density in the soil profile were identified as possible causes of variation of $\mathrm{K}$ leaf contents in grapevine cultivars on different rootstocks, with own-rooted trees as control (IBACACHE; SIERRA, 2009). The $\mathrm{K}$ content is an important variable for fruit quality. Higher levels of this nutrient are usually associated with more colorful fruits and with higher sugar content (NAVA et al., 2008). In addition, K promotes the translocation of the sugars that are produced in the leaves by photosynthesis to the fruits (TAIZ; ZEIGER, 2013), consequently influencing their size and yield.

Regarding the Ca contents, the interaction between factors was only significant in 2014 (Figure 1 and 3). In this year, the Amarelinha, Pluma-7 and Reubennel cultivars presented the highest foliar levels of Ca in ownrooted trees, which were also confirmed in the grafted ones (Figure 3). For the four cultivars (Amarelinha, Blood Plum, Pluma-7 and Reubennel), there were higher $\mathrm{Ca}$ foliar contents for the own-rooted plants, which on average was $30 \%$ higher when compared to the same 
grafted cultivars. In 2015, there was a significant effect of cultivars and of the nursery tree types in the Ca foliar contents, highlighting in the set of data, the Amarelinha, Pluma-7 and Reubennel cultivars with significantly higher content than the other cultivars. In 2015, the own-rooted plants accumulated approximately $25 \%$ more $\mathrm{Ca}$ in the leaves than the grafted plants, but without changing the agronomic interpretation class (CQFS-RS/SC, 2016) (Figure 1). Especially for fruits consumed in natura form, the $\mathrm{Ca}$ sufficiency is primordial for more conservation. Because it is part of the cell wall structure, the Ca increases the plums firmness (VALERO et al., 2002; ALCARAZLOPEZ et al., 2003). However, with the exception of the Amarelinha, Pluma-7 and Reubennel cultivars, which presented normal Ca contents in 2014 (Figure 1), for the others, the data reveal contents below normal (CQFS-RS/ SC, 2016), which indicates that the evaluated cultivars were not efficient to accumulate $\mathrm{Ca}$, even if there were high nutrient contents in the soil (Table 1).

The interaction between the factors was only observed in 2014 (Figure 1 and 4) for the $\mathrm{Mg}$ foliar contents. The Amarelinha, Pluma-7 and Reubennel cultivars presented higher leaf contents in the own-rooted plants (Figure 4). In 2014, the own-rooted plants of the Cerejinha cultivar presented insufficient $\mathrm{Mg}$ contents in the leaves $(0.18 \%)$, approximately $29 \%$ lower than the average of the other cultivars. In relation to the grafted plants, only 'Reubennel' had significantly higher $\mathrm{Mg}$ contents in 2014 than 'Quinze de Novembro' and 'Santa Rita' (Figure 4). Still in 2014, the 'Amarelinha' cultivar, which did not present significant differences between the types of nursery trees (Figure 4), for the others cultivars, the foliar $\mathrm{Mg}$ contents were always higher in the grafted plants than in the own-rooted plants (Figure 4). In 2015, there was only significant effect for the cultivar factor. In this year, the 'Amarelinha', 'Pluma-7; and 'Reubennel' cultivars presented average $\mathrm{Mg}$ contents approximately $40 \%$ higher than the other cultivars (Figure 1). According to the interpretation of the foliar analysis (CQFS-RS/ $\mathrm{SC}, 2016$ ) in both years, the Mg levels were below the range considered normal $(0.50-0.80 \%)$, which may be associated with the irregular distribution of rainfall during the vegetative cycle, since the total monthly rainfall was close to the historical average (Table 2) and the soil $\mathrm{Mg}$ levels were medium or high (Table 1). The lack of humidity in the soil drastically reduces the Mg supply through the mass flow to the root system (BARBER, 1984), which can induce deficiency even though there is good availability of the nutrient in the soil. In addition, it is possible that the reference values of $\mathrm{Mg}$ used for the plum may be overestimated, since the interpretation table (CQFS-RS/SC, 2016) considers the reference values for this crop to be very similar to those used for the peach, and the requirement of $\mathrm{Mg}$ between these crops may be different.
Figure 5 shows the micronutrient leaf contents. Mn was the only micronutrient in which the interaction was significant in the two years of evaluation. In 2014, the 'Amarelinha', 'Reubennel' and 'Santa Rita' cultivars stood out in relation to the other cultivars when the plants were own-rooted (Figure 6). 'Reubennel' and 'Santa Rita' also presented relatively higher Mn contents than the other cultivars, in grafted plants evaluated in 2014 (Figure 6). Regarding the nursery tree types, except for 'Quinze de Novembro' cultivar, the Mn contents in the other cultivars were higher for the own-rooted ones, in 2014. In 2015, the 'Reubennel' and 'Pluma-7' cultivars presented significantly higher contents than 'Cerejinha' and 'Quinze de Novembro', not differing from the others when in own-rooted plants. However, for grafted plants, there were no differences among cultivars in 2015 (Figure 6). In relation to the nursery tree types, own-rooted plants of the 'Amarelinha', 'Blood Plum', 'Pluma-7' and 'Reubennel' cultivars reached higher Mn levels (Figure 6).

As for the $\mathrm{Zn}$ leaf contents, there are differences among the tested cultivars, but the types of nursery tree did not influence (Figure 5). All values were classified as below normal or insufficient (Figure 5 and 7). In 2014, although not different from 'Cerejinha', own-rooted plants of 'Amarelinha' stood out in relation to the other own-rooted cultivars. However, there were no differences between cultivars for grafted plants. In relation to the nursery tree types, 'Amarelinha' was the only cultivar that presented higher levels of $\mathrm{Zn}$ in the own-rooted plants, compared to the grafted ones, even raising the interpretation class in 2014 (CQFS-RS/SC, 2016). This result differs from that reported by Couvillon (1982), who, in own-rooted peach trees, found the reduction of $\mathrm{Zn}$ leaf contents, compared to the plants grafted on 'Lovell' multiplied by seeds. In 2015, there were no differences among cultivars and the nursery tree type in relation to the $\mathrm{Zn}$ leaf content (Figure 5).

Regarding the $\mathrm{Fe}$ content, there was interaction among the factors studied in 2015 (Figure 5 and 8). The own-rooted plants of 'Reubennel' and 'Santa Rita' presented higher contents of $\mathrm{Fe}$ in relation to cvs. 'Amarelinha', 'Blood Plum', 'Cerejinha' and 'Quinze de Novembro' in 2015. In grafted plants, there were no differences among cultivars. In this year of evaluation, own-rooted 'Santa Rita' plants also presented higher Fe content in relation to grafted plants. In 2014, there were no differences among cultivars and the nursery tree type in relation to the Fe leaf content. However, there was an isolated effect of cultivar, 'Santa Rita' presented approximately $80 \%$ more $\mathrm{Fe}$ in its leaves than the average of the other cultivars evaluated (Figure 6), emphasizing its greater efficiency in absorbing this micronutrient from the soil. 
In both evaluation years, the $\mathrm{Fe}$ and $\mathrm{Zn}$ leaf contents (Figure 5, 7 and 8) were below normal or insufficient (CQFS-RS/SC, 2016), which may be related to high soil $\mathrm{pH}$, generally higher than 6.5 (Table 1), which tends to decrease the availability of these micronutrients (ABREU et al., 2007).

Regarding the $\mathrm{Cu}$ contents, there was no significant interaction between the factors studied in any of the evaluation years, but the significant effect of cultivar was evidenced in 2014 and in 2015 (Figure 5). In 2014, the 'Santa Rita' cultivar presented $\mathrm{Cu}$ contents similar to 'Reubennel', but stood out in relation to the others, accumulating approximately $70 \%$ more $\mathrm{Cu}$ than the other cultivars. Regarding the nursery tree type, there was no significant difference in 2014. In 2015, there were differences between cultivars, with 'Amarelinha' and 'Cerejinha' presenting higher levels than 'Quinze de Novembro'. In the same year, the own-rooted plants presented higher concentration of $\mathrm{Cu}$ in the leaves, compared to the grafted ones.

In both evaluation years, the B contents in the leaves were influenced by the cultivar. In 2014, the 'Cerejinha' cultivar presented contents approximately $22 \%$ higher than the average obtained by the 'Amarelinha' and 'Blood Plum' cultivars, but it did not differ significantly from the other cultivars (Figure 5). In 2015, again the 'Cerejinha' cultivar stood out, presenting higher levels in the leaves compared to the 'Blood Plum', 'Reubennel' and 'Santa Rita' cultivars, being able to be considered a cultivar with good absorption capacity of B. In the same year, the ownrooted plants presented higher concentration of $\mathrm{B}$ in the leaves, compared to the grafted ones.

In the analysis of the nutrients, the leaf contents were always higher when the trees were obtained by own-rooted, except for $\mathrm{Mg}$ in 2014. This effect was already evident in other studies (COUVILLON, 1982; COUVILLON, 1985). Own-rooted trees have higher leaf contents of some nutrients such as $\mathrm{Ca}$ and $\mathrm{Mg}$, because they have a greater number of fine roots, which allows the root system to explore larger soil volume, being more efficient in the absorption of water and nutrients, compared to those grafted in rootstocks propagated by seed (COUVILLON, 1982; COUVILLON, 1985). In addition, the grafting point may be a limiting factor, partially blocking the xylem vessels, water and nutrients conductors from the root system to the aerial part of the plant. Thus, the calcium transport can be partially blocked or even prevented by the grafting point (COUVILLON, 1982). Another aspect that may explain the higher efficiency of own-rooted and potted nursery trees is the greater number of roots and that they are able to cover a larger volume of soil, besides not being damaged in the planting because they have roots completely enveloped in the substrate in which they were produced. Thus, they become capable of absorbing more water than grafted plants on rootstocks multiplied by seeds, bare-root (COUVILLON, 1985; MAYER et al., 2014a). However, Couvillon (1982) did not observe any statistical difference in leaf nutrient contents $(\mathrm{N}, \mathrm{P}$, $\mathrm{K}, \mathrm{Ca}, \mathrm{Mg}, \mathrm{Fe}, \mathrm{Mn}, \mathrm{B}, \mathrm{Cu}$ and $\mathrm{Zn}$ ) among six different own-rooted peach tree cultivars, indicating that nutrient absorption variations among own-rooted cultivars are less frequent. Own-rooted peach trees may better withstand low soil humidity conditions compared to plants grafted on 'Lovell', 'Nemaguard' or 'Halford' seedlings, due to the higher leaf water potential and stomatal conductance (COUVILLON et al., 1989).

In four own-rooted scion plum cultivars propagated by micropropagation and compared to the same cultivars grafted on 'Dzhanka 4' seedlings (P.cerasifera), the results regarding vegetative growth varied widely between cultivars. However, in the Reine-Claude d'Althan cultivar, the own-rooted plants grew with greater vigor, forming compact plants with more branches in the first and second years, although they did not influence the beginning of the fruiting (POPOV; KORNOVA, 2009). In three years of field evaluations, Klass and Kahu (2007) concluded that there were no substantial differences in the main characteristics evaluated, such as section area of the trunk, production and fruit mass in nine own-rooted plum cultivars propagated by micropropagation, compared to the same scion grafted on P. cerasifera.

The technology of the own-rooted nursery trees production presents some peculiarities, such as the perpetuation of the genetic identity of the scion and the root system in a single propagation process, the genetic composition of the root system identical to the cultivar scion itself and the exclusion of the risks of graft incompatibility. The use of own-rooted nursery trees may be of particular interest to the plum tree, since plum species are more tolerant to flooding than peach (GUERRA et al., 1992; REIGHARD; LORETI, 2008; MESCHIMIDT et al., 2015). The confirmation of the own-rooted technical feasibility of plum scion cultivars can stimulate the production of nursery trees through tissue culture, high sanity and in a short time. In order to do so, new regional studies and other cultivars of interest are required to prove field viability, especially involving evaluations of plant longevity, yield, productivity, quality and mineral composition of fruits. 


\begin{tabular}{|c|c|c|c|c|c|c|c|c|c|c|}
\hline \multirow{3}{*}{$\begin{array}{l}\text { Factors } \\
\text { contents }\end{array}$} & \multicolumn{2}{|c|}{$\mathrm{N}$} & \multicolumn{2}{|c|}{$\mathrm{P}$} & \multicolumn{2}{|c|}{$\mathrm{K}$} & \multicolumn{2}{|c|}{$\mathrm{Ca}$} & \multicolumn{2}{|c|}{$\mathrm{Mg}$} \\
\hline & \multicolumn{10}{|c|}{$\%$} \\
\hline & 2014 & 2015 & 2014 & 2015 & 2014 & 2015 & 2014 & 2015 & 2014 & 2015 \\
\hline \multicolumn{11}{|l|}{ Cultivar } \\
\hline Blood Plum & $2.24 \mathrm{c}$ & $2.41 \mathrm{bc}$ & $0.27 \mathrm{ab}$ & $0.32 \mathrm{a}$ & $2.04 \mathrm{bc}$ & $2.64 \mathrm{a}$ & $1.28 \mathrm{~b}$ & $1.11 \mathrm{bc}$ & $0.31 \mathrm{bc}$ & $0.31 \mathrm{bc}$ \\
\hline Cerejinha & $2.70 \mathrm{ab}$ & $2.80 \mathrm{ab}$ & $0.28 \mathrm{ab}$ & $0.34 \mathrm{a}$ & $2.14 \mathrm{ab}$ & $2.77 \mathrm{a}$ & $1.07 \mathrm{~b}$ & $0.85 \mathrm{c}$ & $0.27 \mathrm{c}$ & $0.23 \mathrm{c}$ \\
\hline Q. de Novembro & $2.32 \mathrm{c}$ & $2.22 \mathrm{c}$ & $0.27 \mathrm{ab}$ & $0.29 \mathrm{a}$ & $1.71 \mathrm{~d}$ & $2.24 \mathrm{~b}$ & $1.04 \mathrm{~b}$ & $0.81 \mathrm{c}$ & $0.28 \mathrm{c}$ & $0.24 \mathrm{bc}$ \\
\hline Pluma-7 & $2.70 \mathrm{ab}$ & $2.60 \mathrm{abc}$ & $0.31 \mathrm{ab}$ & $0.32 \mathrm{a}$ & $1.95 \mathrm{bc}$ & $2.51 \mathrm{ab}$ & $1.69 \mathrm{a}$ & $1.55 \mathrm{ab}$ & $0.34 \mathrm{ab}$ & $0.35 \mathrm{ab}$ \\
\hline Reubennel & $2.41 \mathrm{bc}$ & $2.46 \mathrm{bc}$ & $0.30 \mathrm{ab}$ & $0.32 \mathrm{a}$ & $2.34 \mathrm{a}$ & $2.74 \mathrm{a}$ & $2.01 \mathrm{a}$ & $1.22 \mathrm{abc}$ & $0.34 \mathrm{ab}$ & $0.33 \mathrm{abc}$ \\
\hline Santa Rita & $2.89 \mathrm{a}$ & $2.95 \mathrm{a}$ & $0.33 \mathrm{a}$ & $0.33 \mathrm{a}$ & $1.86 \mathrm{~cd}$ & $2.58 \mathrm{ab}$ & $1.09 \mathrm{~b}$ & $1.00 \mathrm{c}$ & $0.28 \mathrm{c}$ & $0.28 \mathrm{bc}$ \\
\hline$F_{\text {cultivar }}$ & $10.0584^{* *}$ & $7.0896 * *$ & $2.7833^{*}$ & $0.5169^{\mathrm{ns}}$ & $17.6560 * *$ & $4.5467 * *$ & $24.1430 * *$ & $8.70 * *$ & $11.0634^{* *}$ & $6.6956^{* *}$ \\
\hline \multicolumn{11}{|l|}{ Nursery tree type } \\
\hline Own-rooted & $2.54 \mathrm{a}$ & $2.57 \mathrm{a}$ & $0.29 \mathrm{a}$ & $0.32 \mathrm{a}$ & $2.05 \mathrm{a}$ & $2.61 \mathrm{a}$ & $1.56 \mathrm{a}$ & $1.29 \mathrm{a}$ & $0.28 \mathrm{~b}$ & $0.30 \mathrm{a}$ \\
\hline Grafted & $2.50 \mathrm{a}$ & $2.55 \mathrm{a}$ & $0.28 \mathrm{a}$ & $0.32 \mathrm{a}$ & $1.94 \mathrm{~b}$ & $2.53 \mathrm{a}$ & $1.27 \mathrm{~b}$ & $1.03 \mathrm{~b}$ & $0.34 \mathrm{a}$ & $0.32 \mathrm{a}$ \\
\hline $\mathrm{F}_{\text {nursery tree type }}$ & $0.5262^{\text {ns }}$ & $0.1071^{\mathrm{ns}}$ & $0.1860^{\mathrm{ns}}$ & $0.1133^{\mathrm{ns}}$ & $10.1308^{* *}$ & $1.8507^{\mathrm{ns}}$ & $23.7500^{* *}$ & $10.6713 * *$ & $62.1367 * *$ & $1.5734^{\mathrm{ns}}$ \\
\hline$F_{\text {cultivar } x \text { nurs. tree type }}$ & $0.4544^{\mathrm{ns}}$ & $1.5659^{\mathrm{ns}}$ & $0.9445^{\mathrm{ns}}$ & $0.8914^{\mathrm{ns}}$ & $3.1888 * *$ & $3.6925 * *$ & $2.5130^{*}$ & $1.6303^{\mathrm{ns}}$ & $5.7835 * *$ & $0.6193^{\mathrm{ns}}$ \\
\hline CV (\%) & 9.34 & 11.41 & 18.42 & 19.96 & 7.65 & 10.33 & 17.76 & 28.73 & 11.54 & 27.69 \\
\hline \multicolumn{11}{|c|}{$\begin{array}{l}\text { Averages followed by different letter in column differ by Tukey test. }{ }^{*} \text { significant at the } 5 \% \text { probability level; }{ }^{* *} \text { significant at the } 1 \% \text { probability level; }{ }^{\text {ns }} \text { not significan } \\
\text { nterpretation of the results according to CQFS-RS/SC (2016): }\end{array}$} \\
\hline$=$ below $\mathrm{nc}$ & rmal; & $=$ normal & & D & & & & & & \\
\hline
\end{tabular}

Figure 1. Macronutrient leaf content (\%) in seven plum cultivars established in the field with two types of nursery trees. Embrapa Clima Temperado, Pelotas-RS.

\begin{tabular}{|c|c|c|c|}
\hline & \multicolumn{2}{|c|}{$\mathrm{K}$ leaf contents $(\%)$ in 2014} & \multirow[b]{2}{*}{$F(B$ inside of $A)$} \\
\hline Cultivar & Own-rooted & Grafted & \\
\hline Amarelinha & 1.88 Acd & $1.95 \mathrm{Ab}$ & $0.4685^{\mathrm{ns}}$ \\
\hline Blood Plum & 2.08 Aabc & $2.00 \mathrm{Ab}$ & $0.6544^{\mathrm{ns}}$ \\
\hline Cerejinha & 2.36 Aab & $1.92 \mathrm{Bb}$ & $20.8227 * *$ \\
\hline Q. de Novembro & $1.71 \mathrm{Ad}$ & $1.72 \mathrm{Ab}$ & $0.0039^{\mathrm{ns}}$ \\
\hline Pluma-7 & $2.08 \mathrm{Abc}$ & $1.83 \mathrm{Bb}$ & $6.5088^{*}$ \\
\hline Reubennel & $2.37 \mathrm{Aa}$ & $2.30 \mathrm{Aa}$ & $0.5576^{\mathrm{ns}}$ \\
\hline Santa Rita & 1.88 Acd & $1.84 \mathrm{Ab}$ & $0.2478^{\mathrm{ns}}$ \\
\hline $\mathrm{F}$ (B inside of $\mathrm{A})$ & $13.4312 * *$ & $7.4136^{* *}$ & - \\
\hline $\mathrm{CV}(\%)$ & \multicolumn{2}{|c|}{7.65} & - \\
\hline & \multicolumn{2}{|c|}{ K leaf contents (\%) in 2015} & \\
\hline Cultivar & Own-rooted & Grafted & $F(B$ inside of $A$ ) \\
\hline Amarelinha & $2.37 \mathrm{Ac}$ & $2.64 \mathrm{Aab}$ & $2.4749^{\text {ns }}$ \\
\hline Blood Plum & $2.48 \mathrm{Abc}$ & $2.81 \mathrm{Aa}$ & $3.9141^{\text {ns }}$ \\
\hline Cerejinha & $3.03 \mathrm{Aa}$ & $2.50 \mathrm{Bab}$ & $9.7503 * *$ \\
\hline Q. de Novembro & $2.24 \mathrm{Ac}$ & $2.24 \mathrm{Ab}$ & $0.0001^{\mathrm{ns}}$ \\
\hline Pluma-7 & $2.65 \mathrm{Aabc}$ & 2.37 Aab & $2.9454^{\mathrm{ns}}$ \\
\hline Reubennel & 2.93 Aab & $2.56 \mathrm{Bab}$ & $4.9141^{*}$ \\
\hline Santa Rita & 2.58 Aabc & $2.57 \mathrm{Aab}$ & $0.0070^{\text {ns }}$ \\
\hline $\mathrm{F}$ (B inside of $\mathrm{A})$ & $5.8169^{* *}$ & $2.4223 *$ & \\
\hline CV $(\%)$ & \multicolumn{2}{|c|}{10.33} & \\
\hline \multicolumn{4}{|c|}{$\begin{array}{l}\text { Averages followed by distinct letters, lowercase in the row and upper case in the colur } \\
\text { differ from each other by the Tukey test. * significant at the } 5 \% \text { probability level; } \\
* * \text { significant at the } 1 \% \text { probability level; } \text { "ns not significant. } \\
\text { Interpretation of the results according to CQFS-RS/SC (2016): }\end{array}$} \\
\hline
\end{tabular}

Figure 2. The interaction between the cultivar factors (factor A) and nursery tree type (factor B), for the Potassium variable, in the samplings carried out in 2014 and 2015. Embrapa Clima Temperado, Pelotas-RS. 


\begin{tabular}{lccc}
\hline \multirow{2}{*}{ Cultivar } & \multicolumn{2}{c}{ Ca leaf contents (\%) in 2014 } & \\
\cline { 2 - 3 } & Own-rooted & Grafted & F (B inside of A) \\
\hline Amarelinha & $2.01 \mathrm{Aab}$ & $1.46 \mathrm{Babc}$ & $11.8800^{* *}$ \\
Blood Plum & $1.57 \mathrm{Abc}$ & $0.99 \mathrm{Bcd}$ & $13.3079^{* *}$ \\
Cerejinha & $0.99 \mathrm{Ad}$ & $1.15 \mathrm{Abcd}$ & $1.0640^{\text {ns }}$ \\
Q. de Novembro & $1.11 \mathrm{Acd}$ & $0.97 \mathrm{Ad}$ & $0.7977^{\text {ns }}$ \\
Pluma-7 & $1.85 \mathrm{Aab}$ & $1.52 \mathrm{Bab}$ & $4.3081^{*}$ \\
Reubennel & $2.17 \mathrm{Aa}$ & $1.85 \mathrm{Ba}$ & $4.0509^{*}$ \\
Santa Rita & $1.24 \mathrm{Acd}$ & $0.95 \mathrm{Ad}$ & $3.4194^{\mathrm{ns}}$ \\
\hline F (B inside of A) & $17.0515^{* *}$ & $9.6045^{* *}$ & - \\
\hline CV (\%) & \multicolumn{3}{c}{17.76} \\
\hline Av
\end{tabular}

Averages followed by distinct letters, lowercase in the row and upper case in the column, differ from each other by the Tukey test. * significant at the $5 \%$ probability level; ** significant at the $1 \%$ probability level; ${ }^{\text {ns }}$ not significant.

Interpretation of the results according to CQFS-RS/SC (2016):

= below normal;

Figure 3. The interaction between the cultivar factors (factor A) and nursery tree type (factor B), for the calcium variable, in the sampling carried out in 2014. Embrapa Clima Temperado, Pelotas-RS.

\begin{tabular}{|c|c|c|c|}
\hline \multirow[b]{2}{*}{ Cultivar } & \multicolumn{2}{|c|}{ Mg leaf contents $(\%)$ in 2014} & \multirow[b]{2}{*}{$\mathrm{F}$ ( $\mathrm{B}$ inside of $\mathrm{A})$} \\
\hline & Own-rooted & Grafted & \\
\hline Amarelinha & $0.37 \mathrm{Aa}$ & 0.37 Aabc & $0.0078^{\mathrm{ns}}$ \\
\hline Blood Plum & $0.28 \mathrm{Bb}$ & $0.33 \mathrm{Aabc}$ & $5.2792 *$ \\
\hline Cerejinha & $0.18 \mathrm{Bc}$ & 0.36 Aabc & $60.4766^{* *}$ \\
\hline Q. de Novembro & $0.25 \mathrm{Bb}$ & $0.30 \mathrm{Ac}$ & $4.1312 *$ \\
\hline Pluma-7 & $0.30 \mathrm{Bab}$ & 0.37 Aabc & $9.5666 * *$ \\
\hline Reubennel & $0.30 \mathrm{Bab}$ & $0.38 \mathrm{Aa}$ & $12.4952 * *$ \\
\hline Santa Rita & $0.26 \mathrm{Bb}$ & $0.31 \mathrm{Abc}$ & $4.8809 *$ \\
\hline $\mathrm{F}$ (B inside of $\mathrm{A}$ ) & $12.8514^{* *}$ & $3.9955^{* *}$ & - \\
\hline $\mathrm{CV}(\%)$ & \multicolumn{2}{|c|}{11.54} & - \\
\hline \multicolumn{4}{|c|}{$\begin{array}{l}\text { Averages followed by distinct letters, lowercase in the row and upper case in the column } \\
\text { differ from each other by the Tukey test. * significant at the 5\% probability level; } \\
* * \text { significant at the } 1 \% \text { probability level; }{ }^{\text {ns }} \text { not significant. } \\
\text { Interpretation of the results according to CQFS-RS/SC (2016): } \\
=\text { insufficient; }\end{array}$} \\
\hline
\end{tabular}

Figure 4. The interaction between the cultivar factors (factor A) and nursery tree type (factor B), for the Magnesium variable, in the sampling carried out in 2014. Embrapa Clima Temperado, Pelotas-RS.

\begin{tabular}{|c|c|c|c|c|c|c|c|c|c|c|}
\hline \multirow{3}{*}{$\begin{array}{l}\text { Factors } \\
\text { contents }\end{array}$} & \multicolumn{2}{|c|}{$\mathrm{Fe}$} & \multirow{2}{*}{\multicolumn{2}{|c|}{$\mathrm{Mn}$}} & \multirow{2}{*}{\multicolumn{2}{|c|}{$\frac{\mathrm{Zn}}{\mathrm{mg} \mathrm{kg}}$}} & \multicolumn{2}{|c|}{$\mathrm{Cu}$} & \multicolumn{2}{|c|}{ B } \\
\hline & & & & & & & & & & \\
\hline & 2014 & 2015 & 2014 & 2015 & 2014 & 2015 & 2014 & 2015 & 2014 & 2015 \\
\hline \multicolumn{11}{|l|}{ Cultivar } \\
\hline Amarelinha & $47.8 \mathrm{bc}$ & $53.8 \mathrm{abc}$ & $72.8 \mathrm{a}$ & $60.5 \mathrm{abc}$ & $10.4 \mathrm{a}$ & $15.6 \mathrm{a}$ & $5.4 \mathrm{~b}$ & $12.1 \mathrm{a}$ & $40.7 \mathrm{bc}$ & $47.1 \mathrm{ab}$ \\
\hline Blood Plum & $34.7 \mathrm{~cd}$ & $41.7 \mathrm{c}$ & $45.4 \mathrm{~b}$ & $61.3 \mathrm{abc}$ & $7.6 \mathrm{ab}$ & $12.9 \mathrm{a}$ & $3.7 \mathrm{bc}$ & $10.8 \mathrm{ab}$ & $39.9 \mathrm{c}$ & $44.9 \mathrm{~b}$ \\
\hline Cerejinha & $40.6 \mathrm{~cd}$ & $46.4 \mathrm{bc}$ & $35.8 \mathrm{~b}$ & $41.1 \mathrm{c}$ & $7.7 \mathrm{ab}$ & $14.2 \mathrm{a}$ & $4.7 \mathrm{bc}$ & $12.1 \mathrm{a}$ & $49.1 \mathrm{a}$ & $52.2 \mathrm{a}$ \\
\hline Q. de Novembro & $32.5 \mathrm{~d}$ & $42.1 \mathrm{c}$ & $37.1 \mathrm{~b}$ & $48.8 \mathrm{bc}$ & $5.9 \mathrm{~b}$ & $15.5 \mathrm{a}$ & $2.9 \mathrm{c}$ & $9.1 \mathrm{~b}$ & $45.7 \mathrm{abc}$ & $46.4 \mathrm{ab}$ \\
\hline Pluma-7 & $38.4 \mathrm{~cd}$ & $52.5 \mathrm{abc}$ & $46.0 \mathrm{~b}$ & $73.1 \mathrm{a}$ & $6.2 \mathrm{~b}$ & $15.5 \mathrm{a}$ & $4.2 \mathrm{bc}$ & $10.9 \mathrm{ab}$ & $44.9 \mathrm{abc}$ & $45.3 \mathrm{ab}$ \\
\hline Reubennel & $59.3 \mathrm{~b}$ & $67.3 \mathrm{a}$ & $67.0 \mathrm{a}$ & $68.5 \mathrm{ab}$ & $6.4 \mathrm{~b}$ & $12.6 \mathrm{a}$ & $5.6 \mathrm{ab}$ & $10.8 \mathrm{ab}$ & $46.3 \mathrm{ab}$ & $42.5 \mathrm{~b}$ \\
\hline Santa Rita & $75.2 \mathrm{a}$ & $63.4 \mathrm{ab}$ & $79.7 \mathrm{a}$ & $66.1 \mathrm{ab}$ & $9.0 \mathrm{ab}$ & $11.7 \mathrm{a}$ & $7.5 \mathrm{a}$ & $11.2 \mathrm{ab}$ & $43.9 \mathrm{abc}$ & $42.8 \mathrm{~b}$ \\
\hline$F_{\text {cultivar }}$ & $24.8872 * *$ & $5.9617 * *$ & $15.0333^{* *}$ & $5.6274 * *$ & $4.1737 * *$ & $1.3366^{\mathrm{ns}}$ & $9.8385 * *$ & $3.0732 *$ & $5.4457 * *$ & $4.0128 * *$ \\
\hline \multicolumn{11}{|l|}{ Nursery tree type } \\
\hline Own-1 & $46.7 \mathrm{a}$ & $53.1 \mathrm{a}$ & $72.3 \mathrm{a}$ & $75.5 \mathrm{a}$ & $7.9 \mathrm{a}$ & $14.2 \mathrm{a}$ & $4.77 \mathrm{a}$ & $11.9 \mathrm{a}$ & $44.8 \mathrm{a}$ & $47.5 \mathrm{a}$ \\
\hline Grafted & $47.1 \mathrm{a}$ & $51.8 \mathrm{a}$ & $37.3 \mathrm{~b}$ & $44.3 \mathrm{~b}$ & $7.3 \mathrm{a}$ & $13.8 \mathrm{a}$ & $4.94 \mathrm{a}$ & $10.1 \mathrm{~b}$ & $43.9 \mathrm{a}$ & $44.2 \mathrm{~b}$ \\
\hline $\mathrm{F}_{\text {nursery tree type }}$ & $0.0253^{\mathrm{ns}}$ & $0.1957^{\mathrm{ns}}$ & $100.2007 * *$ & $75.13^{* *}$ & $0.7199^{\mathrm{ns}}$ & $0.1885^{\mathrm{ns}}$ & $0.2256^{\mathrm{ns}}$ & $16.4382 * *$ & $0.6350^{\mathrm{ns}}$ & $7.2420 * *$ \\
\hline$F_{\text {cultivar } x}$ & $1.2361^{\mathrm{ns}}$ & $3.2629 * *$ & $5.1752 * *$ & $2.9279 *$ & $4.7381 * *$ & $0.7554^{\mathrm{ns}}$ & $2.1265^{\mathrm{ns}}$ & $1.3713^{\mathrm{ns}}$ & $2.1062^{\text {ns }}$ & $1.2468^{\mathrm{ns}}$ \\
\hline $\mathrm{F}_{\text {Blocks }}$ & $2.0027^{\mathrm{ns}}$ & $5.9436 * *$ & $2.8216^{*}$ & $10.8244 * *$ & $2.4142^{\mathrm{ns}}$ & $6.0025 * *$ & $1.0810^{\mathrm{ns}}$ & $26.8125 * *$ & $1.7839^{\mathrm{ns}}$ & $0.8000^{\mathrm{ns}}$ \\
\hline CV (\%) & 20.81 & 24.72 & 26.70 & 25.13 & 33.36 & 31.46 & 31.09 & 16.62 & 9.81 & 11.23 \\
\hline
\end{tabular}

Averages followed by different letter in column differ by Tukey test. * significant at the $5 \%$ probability level; ** significant at the $1 \%$ probability level;

${ }^{\text {ns }}$ not significant. Interpretation of the results according to CQFS-RS/SC (2016):

not significant. Interpretation of the results according to CQFS-RS/SC (2016):

Figure 5. Micronutrient leaf content $\left(\mathrm{mg} \mathrm{kg}^{-1}\right)$ in seven plum cultivars established in the field with two nursery tree types. Embrapa Clima Temperado, Pelotas-RS. 


\begin{tabular}{|c|c|c|c|}
\hline \multirow[b]{2}{*}{ Cultivar } & \multicolumn{2}{|c|}{ Mn leaf contents $\left(\mathrm{mg} \mathrm{kg}^{-1}\right)$ in 2014} & \multirow[b]{2}{*}{$\mathrm{F}(\mathrm{B}$ inside of $\mathrm{A})$} \\
\hline & Own-rooted & Grafted & \\
\hline Amarelinha & $109.2 \mathrm{Aa}$ & $36.4 \mathrm{Bb}$ & $61.8288 * *$ \\
\hline Blood Plum & $58.6 \mathrm{Ab}$ & $32.2 \mathrm{Bb}$ & $8.1308 * *$ \\
\hline Cerejinha & $49.0 \mathrm{Ab}$ & $22.6 \mathrm{Bb}$ & $8.1308 * *$ \\
\hline Q. de Novembro & $40.8 \mathrm{Ab}$ & $33.4 \mathrm{Ab}$ & $0.6388^{\mathrm{ns}}$ \\
\hline Pluma-7 & $61.8 \mathrm{Ab}$ & $30.2 \mathrm{Bb}$ & $11.6494 * *$ \\
\hline Reubennel & $92.8 \mathrm{Aa}$ & 41.2 Bab & $31.0618 * *$ \\
\hline Santa Rita & $94.2 \mathrm{Aa}$ & $65.2 \mathrm{Ba}$ & $9.8112 * *$ \\
\hline $\mathrm{F}(\mathrm{B}$ inside of $\mathrm{A})$ & $15.9225 * *$ & $4.2859 * *$ & - \\
\hline CV (\%) & \multicolumn{2}{|c|}{26.70} & - \\
\hline & \multicolumn{2}{|c|}{ Mn leaf contents $\left(\mathrm{mg} \mathrm{kg}^{-1}\right)$ in 2015} & \\
\hline Cultivar & Own-rooted & Grafted & $\mathrm{F}(\mathrm{B}$ inside of $\mathrm{A})$ \\
\hline Amarelinha & $76.2 \mathrm{Aab}$ & $44.8 \mathrm{Ba}$ & $10.8705 * *$ \\
\hline Blood Plum & $78.4 \mathrm{Aab}$ & $44.2 \mathrm{Ba}$ & $12.8957 * *$ \\
\hline Cerejinha & $49.8 \mathrm{Ab}$ & $32.4 \mathrm{Aa}$ & $3.3380^{\mathrm{ns}}$ \\
\hline Q. de Novembro & $58.2 \mathrm{Ab}$ & $39.4 \mathrm{Aa}$ & $3.8968^{\mathrm{ns}}$ \\
\hline Pluma-7 & $101.0 \mathrm{Aa}$ & $45.2 \mathrm{Ba}$ & $34.3289 * *$ \\
\hline Reubennel & $92.6 \mathrm{Aa}$ & $44.4 \mathrm{Ba}$ & $25.6145 * *$ \\
\hline Santa Rita & $72.4 \mathrm{Aab}$ & $59.8 \mathrm{Aa}$ & $1.7504^{\mathrm{ns}}$ \\
\hline $\mathrm{F}(\mathrm{B}$ inside of $\mathrm{A})$ & $7.0597 * *$ & $1.4956^{\mathrm{ns}}$ & - \\
\hline CV (\%) & \multicolumn{2}{|c|}{25.13} & - \\
\hline
\end{tabular}

Averages followed by distinct letters, lowercase in the row and upper case in the column, differ from each other by the Tukey test. * significant at the $5 \%$ probability level;

** significant at the $1 \%$ probability level; ${ }^{\text {ns }}$ not significant.

Interpretation of the results according to CQFS-RS/SC (2016):

= below normal; $\square=$ normal.

Figure 6. The interaction between the cultivar factors (factor A) and nursery tree type (factor B), for the manganese variable, in the samplings carried out in 2014 and 2015. Embrapa Clima Temperado, Pelotas-RS.

\begin{tabular}{|c|c|c|c|}
\hline \multicolumn{4}{|c|}{ Zn leaf contents ( $\left.\mathrm{mg} \mathrm{kg}^{-1}\right)$ in 2014} \\
\hline Cultivar & Own-rooted & Grafted & $\mathrm{F}(\mathrm{B}$ inside of $\mathrm{A})$ \\
\hline Amarelinha & $14.0 \mathrm{Aa}$ & $6.8 \mathrm{Ba}$ & $20.1583^{* *}$ \\
\hline Blood Plum & $6.2 \mathrm{Ab}$ & $9.0 \mathrm{Aa}$ & $3.0486^{\mathrm{ns}}$ \\
\hline Cerejinha & 9.2 Aab & $6.2 \mathrm{Aa}$ & $3.4997^{\mathrm{ns}}$ \\
\hline Q. de Novembro & $5.4 \mathrm{Ab}$ & $6.4 \mathrm{Aa}$ & $0.3889^{\text {ns }}$ \\
\hline Pluma-7 & $6.4 \mathrm{Ab}$ & $6.0 \mathrm{Aa}$ & $0.0622^{\mathrm{ns}}$ \\
\hline Reubennel & $5.6 \mathrm{Ab}$ & $7.2 \mathrm{Aa}$ & $0.9955^{\mathrm{ns}}$ \\
\hline Santa Rita & $8.2 \mathrm{Ab}$ & $9.8 \mathrm{Aa}$ & $0.9955^{\text {ns }}$ \\
\hline $\mathrm{F}$ (B inside of $\mathrm{A})$ & $7.2142 * *$ & $1.6976^{\mathrm{ns}}$ & - \\
\hline CV (\%) & & & - \\
\hline
\end{tabular}

Figure 7. The interaction between the cultivar factors (factor A) and nursery tree type (factor B), for the Zinc variable, in the sampling carried out in 2014. Embrapa Clima Temperado, Pelotas-RS. 


\begin{tabular}{lccc}
\hline \multirow{2}{*}{ Cultivar } & \multicolumn{2}{c}{ Fe leaf contents $\left(\mathrm{mg} \mathrm{kg}^{-1}\right)$ in 2015} & \\
\cline { 2 - 3 } & Own-rooted & Grafted & F (B inside of A) \\
\hline Amarelinha & $45.8 \mathrm{Ab}$ & $61.8 \mathrm{Aa}$ & $3.8057^{\mathrm{ns}}$ \\
Blood Plum & $42.4 \mathrm{Ab}$ & $41.0 \mathrm{Aa}$ & $0.0291^{\mathrm{ns}}$ \\
Cerejinha & $39.6 \mathrm{Ab}$ & $53.2 \mathrm{Aa}$ & $2.7496^{\mathrm{ns}}$ \\
Q. de Novembro & $38.6 \mathrm{Ab}$ & $45.6 \mathrm{Aa}$ & $0.7284^{\mathrm{ns}}$ \\
Pluma-7 & $55.8 \mathrm{Aab}$ & $49.2 \mathrm{Aa}$ & $0.6476^{\mathrm{ns}}$ \\
Reubennel & $74.0 \mathrm{Aa}$ & $60.6 \mathrm{Aa}$ & $2.6694^{\mathrm{ns}}$ \\
Santa Rita & $75.8 \mathrm{Aa}$ & $51.0 \mathrm{Ba}$ & $9.1433^{* *}$ \\
\hline F (B inside of A) & $7.5305^{* *}$ & $1.6941^{\mathrm{ns}}$ & - \\
\hline CV (\%) & \multicolumn{2}{c}{24.72} & - \\
\hline C & \multicolumn{3}{c}{}
\end{tabular}

Averages followed by distinct letters, lowercase in the row and upper case in the column, differ from each other by the Tukey test. * significant at the $5 \%$ probability level;

** significant at the $1 \%$ probability level; ${ }^{\text {ns }}$ not significant.

Interpretation of the results according to CQFS-RS/SC (2016):

insufficient;

$=$ below normal.

Figure 8. The interaction between the cultivar factors (factor A) and nursery tree type (factor B), for the Iron variable, in the sampling carried out in 2015. Embrapa Clima Temperado, Pelotas-RS.

\section{Conclusion}

The leaf nutrient content of Japanese plums varies among cultivars, but there is no cultivar that stands out in all macro (N, P, K, Ca and $\mathrm{Mg}$ ) and micronutrients (Fe, $\mathrm{Mn}, \mathrm{Zn}, \mathrm{Cu}$ and $\mathrm{B}$ ) evaluated.

Potassium, calcium and manganese leaf contents, when influenced by the nursery tree types tested, were always higher in own-rooted plants. However, the foliar magnesium contents, when influenced by the nursery trees types tested, were always higher in plants grafted on 'Capdeboscq'.

The own-rooted plants of 'Amarelinha', 'Blood Plum', 'Pluma-7' and 'Reubennel' cultivars presented higher manganese leaf contents, in relation to the grafted trees of these cultivars on 'Capdeboscq'.

The own-rooted trees of 'Cerejinha' present higher potassium leaf contents in relation to the grafted plants of this cultivar on 'Capdeboscq' and, even, rise the agronomic interpretation class.

\section{References}

ABREU, C.A.; LOPES, A.S.; SANTOS, G. Micronutrientes. In: NOVAIS, R.F.; ALVAREZ, V.H.; BARROS, N.F.; FONTES, R.L.F.; CANTARUTTI, R.B.; NEVES, J.C.L. (Ed.). Fertilidade do solo. Viçosa: Sociedade Brasileira de Ciência do Solo, 2007. p.645736.
ALCARAZ-LOPEZ, C.; BOTIA, M.; ALCARAZ, C.F.; RIQUELME, F. Effects of foliar sprays containing calcium, magnesium and titanium on plum (Prunus domestica L.) fruit quality. Journal of Plant Physiology, Heidelberg, v.160, n.12, p.1441-1446, 2003.

BANDEIRA, J.M.; SILVA, C.P.; THUROW, L.B.; BRAGA, E.J.B.; PETERS, J.A.; BIANCHI, V.J. In vitro establishment and multiplication of Japanese plum cv. América. Revista de la Facultad de Agronomía, La Plata, v.112, n.1, p.44-50, 2013.

BARBER, S.A. Soil nutrient biovailability: a mechanistic approach. New York: John \& Wiley, 1984. 398p.

BRUNETTO, G.; NAVA, G.; AMBROSINI, V.G.; COMIN, J.J; KAMINSKI, J. The pear tree response to phosphorus and potassium fertilization. Revista Brasileira de Fruticultura, Jaboticabal, v.37, n.2, p.507516, 2015.

CARNEIRO, R.M.D.G.; CAMPOS, A.D.; PEREIRA, J.F.M.; RASEIRA, M. do C.B. Avaliação de porta-enxertos de Prunus quanto à suscetibilidade ao nematóide anelado e ao conteúdo de enzimas fenol oxidases. Nematologia Brasileira, Campinas, v.22, n.1, p.32-38, 1998.

CASTRO, L.A.S.; MEDEIROS, A.R.M. Uso da alporquia na propagação da ameixeira européia cv. Stanley (Prunus domestica). Pelotas: Embrapa Clima Temperado, 2007. 20p. (Boletim de Pesquisa e Desenvolvimento, 60).

CQFS-RS/SC - Comissão de Química e Fertilidade do Solo. Manual de adubação e calagem para os estados do Rio Grande do Sul e de Santa Catarina. 10.ed. Porto Alegre: SBCS - Núcleo Regional Sul/UFRGS, 2004. 400p. 
CQFS-RS/SC - Comissão de Química e Fertilidade do Solo. Manual de calagem e adubação para os estados do Rio Grande do Sul e de Santa Catarina. 11.ed. Santa Maria: SBCS - Núcleo Regional Sul, 2016. 376p.

COUVILLON, G.A. Leaf elemental content comparisons of own-rooted peach cultivars to the same cultivars on several peach seedling rootstocks. Journal American Society for Horticultural Science, Alexandria, v.107, n.4, p.555-558, 1982.

COUVILLON, G.A. Propagation and performance of inexpensive peach trees from cuttings for high density peach plantings. Acta Horticulturae, The Hague, n.173, p.271-281, 1985.

COUVILLON, G.A.; RIEGER, M.; HARRISON, R.; DANIELL, J.; APARISI, J.G. Stress-mediated responses of own rooted peach cultivars. Acta Horticulturae, The Hague, n.243, p.221-230, 1989.

DUtRA, L.F.; TONIETtO, A.; KeRSTEN, E. Enraizamento de estacas de ameixeira (Prunus salicina lindl) tratadas com ácido indolbutírico e ethephon. Revista Brasileira de Agrociência, Pelotas, v.3, n.2, p.59-64, 1997.

EMBRAPA-Empresa Brasileira de Pesquisa Agropecuária. Sistema brasileiro de classificação de solos. 3.ed. Brasília, 2013. 353p.

ESTAT. Sistema para análises estatísticas (v. 2.0). Jaboticabal: Departamento de Ciências Exatas, FCAV, UNESP, 1994.

FREIRE, C.J.S. Recomendação de adubação potássica de manutenção para a cultura da ameixeira por meio da análise foliar. Pelotas: Embrapa Clima Temperado, 2002. 2p. (Comunicado Técnico, 67).

FREIRE, C.J.S.; MAGNANI, M. Manual de coleta de amostras de folhas, para diagnose nutricional, das principais frutíferas cultivadas no RS e em SC. Pelotas: Embrapa Clima Temperado, 2005. 18p. (Documentos, 142).

GUERRA, L.J.; FINARDI, N.L.; SANTOS FILHO, B.G. dos.; PETERS, J.A. Influência do alagamento na mortalidade do pessegueiro e da ameixeira. Pesquisa Agropecuária Brasileira, Brasília, DF, v.27, n.3, p.499508, 1992.

HAMMERSCHLAG, F.A.; SCORZA, R. Field performance of micropropagated, own-rooted peach trees. Journal American Society for Horticultural Science, Alexandria, v.116, n.6, p.1089-1091, 1991.
IBACACHE, A.; SIERRA, C. Influence of rootstocks on nitrogen, phosphorus and potassium content in petioles of four table grape varieties. Chilean Journal of Agricultural Research, Chillán, v.69, n.4, p.503-508, 2009.

KLAAS, L.; KAHU, K. Effect of two propagation methods on growth and fruit yield of plum cultivars. Acta Horticulturae, The Hague, n.734, p.305-308, 2007.

MANGANARIS, G.A.; VASILAKAKIS, M.; MIGNANI, I.; DIAMANTIDIS, G.; TZAVELLA-KLONARI, K. The effect of preharvest calcium sprays on quality attributes, physicochemical aspects of cell wall components and susceptibility to brown rot of peach fruits (Prunus persica L. cv. Andross). Scientia Horticulturae, New York, v.107, p.43-50, 2005.

MAYER, N.A.; BIANCHI, V.J.; CASTRO, L.A.S. Portaenxertos. In: RASEIRA, M.C.B., PEREIRA, J.F.M., CARVALHO, F.L.C. Pessegueiro. Brasília, DF: Embrapa, 2014a. p.173-223.

MAYER, N.A.; UENO, B.; FISCHER, C. Efeito de tipos de mudas no crescimento inicial de sete cultivares de ameixeiras. In: CONGRESSO BRASILEIRO DE FRUTICULTURA, 23., 2014, Cuiabá. Anais... 2014b. 1 CD-ROM.

MAUCH, C.H.; MAUCH, N.; FINARDI, N.L. Reações de pessegueiros e da ameixeira ao nematóide das galhas Meloidogyne incognita. Nematologia Brasileira, Campinas, v.15, n.1, p.59-67, 1991.

MESCHIMIDT, A.A.; BIANCHI, V.J.; ZANANDREA, I.; MATINAZZO, E.G.; RADMANN, E.B.; BACARIN, M.A. Trocas gasosas e atividade antioxidante de portaenxertos de Prunus spp. submetidos ao estresse seca e alagamento. Revista de la Facultad de Agonomía, La Plata, v.114. n.1, p. 71-81, 2015.

NAVA, G.; DECHEN, A.R.; NACHTIGALL, G.R. Nitrogen and potassium fertilization affect apple fruit quality in Southern Brazil. Communication in Soil Science and Plant Analysis, Athens, v.39, p.96-107, 2008.

NAVA, G.; DECHEN, A.R.; NACHTIGALL, G.R.; KATSURAYAMA, J.M.; ROCCO, M.A. Composição mineral de folhas em duas épocas de amostragem e vigor da macieira 'Fuji' em resposta a nitrogênio e potássio. Revista Agropecuária Catarinense, Florianopolis, v.23, n.2, p.77-83, 2010. 
NAVA, G.; SANTOS, K.L.; COSTA, M. D.; CIOTTA, M.N. Growth, mineral composition, fruit yield, and mycorrhizal colonization of feijoa in response to lime and phosphorus application. Pesquisa Agropecuária Brasileira, Brasília, DF, v.51, p.942-949, 2016.

NAVA, G.; CIOTTA, M.N.; BRUNETTO, G. 'Fuji' apple tree response to phosphorus fertilization. Revista Brasileira de Fruticultura, Jaboticabal, v.39, n.1, p.1-8, 2017.

PEREIRA, F.M.; MAYER, N.A. Pessegueiro: tecnologias para a produção de mudas. Jaboticabal: Funep, 2005. $65 \mathrm{p}$.

POPOV, S.; ZHIVONDOV, A. Behaviour of micropropagated own-rooted trees of plum cv. Stanley in the orchard. 3. Morphological and pomological characteristics. Acta Horticulturae, The Hague, n.577, p.379-384, 2002.

POPOV, S.K.; KORNOVA, K.M. Shoot growth structure of own-rooted micropropagated plum cultivars in the juvenile period. Acta Horticulturae, The Hague, n.825, p.497-502, 2009.

RASEIRA, A.; PEREIRA, J.F.M.; CASTRO, L.A.S.; FINARDI, N.L. Poda e condução. In: CASTRO, L.A.S. Ameixa. Produção. Brasília, DF: Embrapa Clima Temperado, 2003. p.50-55.

REIGHARD, G.L.; WATSON, W.A.; COSTON, D.C.; RIDLEY, J.D. Survival of own-rooted and budded 'Redhaven' trees on a Peach Tree Short Life site. HortScience, Alexandria, v.25, n.3, p.359, 1990.
REIGHARD, G.L.; LORETI, F. Rootstock development. In: LAYNE, D.; BASSI, D. The Peach: botany, production and uses. Wallingford: CAB International, 2008. p.193220 .

SCHWENGBER, J.E.; DUTRA, L.F.; TONIETTO, A.; KERSTEN, E. Utilização de diferentes recipientes na propagação da ameixeira através de estacas. Revista Brasileira de Fruticultura, Jaboticabal, v.24, n.1, p.285288, 2002.

TAIZ, L.; ZEIGER, E. Fisiologia vegetal. 5. ed. Porto Alegre: Artmed, 2013. 954 p.

TEDESCO, M.J.; GIANELLO, C.; BISSANI, C.A.; BOHNEN, S.J. Análise de solo, plantas e outros materiais. 2.ed. Porto Alegre: Universidade Federal do Rio Grande do Sul, 1995. 147p. (Boletim Técnico, 5).

TOFANELLI, M.B.D.; CHALFUN, N.N.J.; HOFFMANN, A.; CHALFUN JÚNIOR, A. Enraizamento de estacas lenhosas e semilenhosas de cultivares de ameixeira com várias concentrações de ácido indolbutírico. Revista Brasileira de Fruticultura, Jaboticabal, v.24, n.2, p.509513, 2002.

TONIETTO, A.; FORTES, G.R.L.; SILVA, J.B. Enraizamento de miniestacas de ameixeira. Revista Brasileira de Fruticultura, Jaboticabal, v.23, n.2, p.373376, 2001.

VALERO, D.A.; PEREZ-VICENTE, D.; MARTÍNEZROMERO, S.; CASTILLO, F. GUILLEN, SERRANO, M. Plum storability improved after calcium and heat postharvest treatments: role of polyamines. Journal of Food Science, Medford, v.67, p. 2571-2575, 2002. 